\title{
Discharge of debris from ice at the margin of the Greenland ice sheet
}

\author{
Peter G. KNight, ${ }^{1}$ Righard I. Waller,,${ }^{1}$ Carrie J. Patterson, ${ }^{2}$ Alison P. JOnes, ${ }^{3}$ \\ ZOE P. ROBINSON ${ }^{1}$ \\ ${ }^{1}$ School of Earth Sciences and Geography, Keele University, Keele, Staffordshire ST5 5BG, England \\ E-mail:p.g.knight@keele.ac.uk \\ ${ }^{2}$ Minnesota Geological Survey/University of Minnesota, 2642 University Avenue, St Paul, Minnesota 55114-1057, U.S.A. \\ ${ }^{3}$ Department of Geography, University of Liverpool, Liverpool L69 3BX, England
}

\begin{abstract}
Sediment production at a terrestrial section of the ice-sheet margin in West Greenland is dominated by debris released through the basal ice layer. The debris flux through the basal ice at the margin is estimated to be $12-45 \mathrm{~m}^{3} \mathrm{~m}^{-1} \mathrm{a}^{-1}$. This is three orders of magnitude higher than that previously reported for East Antarctica, an order of magnitude higher than sites reported from in Norway, Iceland and Switzerland, but an order of magnitude lower than values previously reported from tidewater glaciers in Alaska and other high-rate environments such as surging glaciers. At our site, only negligible amounts of debris are released through englacial, supraglacial or subglacial sediment transfer. Glaciofluvial sediment production is highly localized, and long sections of the ice-sheet margin receive no sediment from glaciofluvial sources. These findings differ from those of studies at more temperate glacial settings where glaciofluvial routes are dominant and basal ice contributes only a minor percentage of the debris released at the margin. These data on debris flux through the terrestrial margin of an outlet glacier contribute to our limited knowledge of debris production from the Greenland ice sheet.
\end{abstract}

\section{INTRODUCTION}

Debris-rich basal ice can provide an important pathway for the transport of glacial debris, contributing to the formation of depositional landforms and thus to the stability of glacier margins (e.g. Post, 1975; Powell, 1991; Hunter and others, 1996b; Fitzsimons, 1997). The debris composition of basal ice has been described in detail at a variety of locations (e.g. Lawson, 1979; Sharp and others, 1994; Hubbard and Sharp, 1995), but relatively little work has examined how the flux of debris through the basal ice layer contributes to glacial sediment budgets. Furthermore, although most Pleistocene glacial sediments are derived from former ice-sheet environments, most studies of modern glacial sediment budgets have been derived from valley glaciers in alpine settings (e.g. Small and others, 1984; Evenson and Clinch, 1987; Small, 1987; Hunter and others 1996a). Very little information is available about the flux of debris through ice in modern icesheet settings or from polar glaciated basins. Hallet and others (1996) provided data on glacial sediment yields compiled from literature on more than 60 sites, and their review revealed both the predominance of data from valley and fjord settings, and the limited availability of specific information about debris flux through the basal ice layer. None of the sites they reported related to terrestrial ice-sheet margins, and many of them derived sediment yields from erosional or depositional records rather than from direct measurements of glacial debris content.

The relative abundance of debris in supraglacial, englacial, basal-ice and deforming substrate locations is an important control on glacial sedimentary processes and features, and may vary substantially between ice sheets and valley glaciers. This paper provides data on the discharge of debris from ice at a section of the margin of the Greenland ice sheet, and compares the distribution and characteristics of ice-sheet debris at this site with previously published observations from other locations. In terms of its morphology and debris composition, the section of the ice sheet that we studied is representative of $\sim 77 \%$ of the ice margin in West Greenland, and thus provides data that can be used to estimate debris flux for a significant type of terrestrial ice-sheet margin. Our current knowledge of sediment flux through the basal ice of continental ice sheets is extremely limited, and although this paper provides only a limited dataset, it is of a type that is not well represented in previous literature.

\section{METHODS}

The facies structure and debris composition of basal ice were observed around the margin of the Russell-Leverett outlet lobe near Kangerlussuaq, West Greenland $\left(67^{\circ} \mathrm{N}, 50^{\circ} \mathrm{W}\right.$; Fig. 1). The distributions and thickness of different basal ice facies in this area were previously observed along $20 \mathrm{~km}$ of ice margin between 1984 and 1993 (e.g. Sugden and others, 1987; Knight, 1994; Knight and others, 1994). We collected additional measurements of facies characteristics and debris content along a $1 \mathrm{~km}$ section of the northern flank of the lobe in 1999. The $1 \mathrm{~km}$ section used for the present study was chosen because our previous work had shown it to contain the whole range of ice facies characteristic of the ice margin in the region, and because it was a confined zone of entirely 


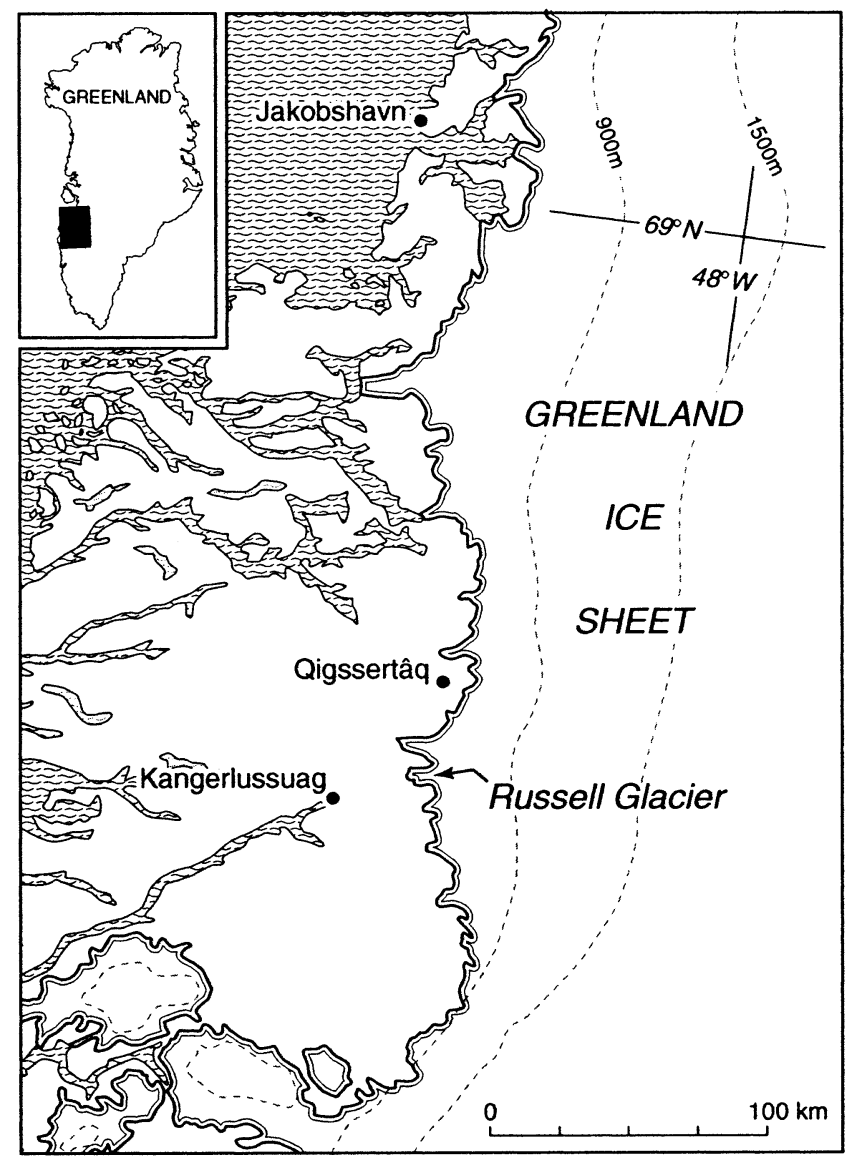

Fig. 1. Map of part of the western margin of the Greenland ice sheet, showing the location of the Russell Glacier study area and other sites referred to in the text.

terrestrial margin, unaffected by meltwater streams, in between subglacial drainage outlets. Over the $12 \mathrm{~km}$ length of the northern flank of Russell Glacier, of which our study area was a part, only six subglacial water outlets were observed, and $>11 \mathrm{~km}$ of the margin was unaffected by glaciofluvial sources other than minor supraglacial in-wash. Comparative studies at Quigssertaq, $40 \mathrm{~km}$ north of our site (Souchez and others, 1990, 1993; Knight and others, 1994), and at Jakobshavn Isbræ, $250 \mathrm{~km}$ north (Sugden and others, 1987), have indicated that both the ice-margin morphology and the basal ice stratigraphy are broadly consistent over long distances throughout this area. Our study area is characteristic of a significant topographic and hydrological environment. The recent glacial history of the site was described by Knight and others (2000).

The thickness of distinctive facies in the basal ice sequence was measured directly at the ice margin. Where facies were not horizontal, thickness was measured perpendicular to the angle of dip of the facies boundary. Access to exposures was achieved at the frontal ice cliff, in subglacial cavities at the margin, and in crevasses penetrating both from the bed and from the surface of the glacier. Particle-size distributions of debris from each facies (Table 1) were determined by measuring large clasts individually in the field and by sieving and hydrometer analysis of bulk debris samples returned to the laboratory. Samples of debris-bearing ice (each $\sim 2000 \mathrm{~cm}^{3}$ ) were excavated from the ice using an ice axe after removing $\mathrm{a} \sim 20 \mathrm{~cm}$ surface layer. Debris content as percentage volume debris in ice for all facies was calculated by melting samples of debris-bearing ice, measuring the volume of the total sample (water and debris), drying the sample and then measuring the volume of debris by displacement of liquid. The percen-
Table 1. Particle-size distribution (\% volume) of debris in dispersed and stratified facies of the basal ice at Russell Glacier

\begin{tabular}{|c|c|c|c|c|c|}
\hline \multirow[b]{2}{*}{ Facies } & \multirow[b]{2}{*}{ Clay } & \multicolumn{3}{|c|}{ Particle-size distribution } & \multirow[b]{2}{*}{ Boulders } \\
\hline & & Silt & Sand & Gravel & \\
\hline Dispersed & 20.0 & 70.0 & 10.0 & 0.0 & 0.0 \\
\hline Stratified & 1.5 & 13.5 & 27.0 & 48.0 & 10.0 \\
\hline
\end{tabular}

Table 2. Thickness, and percentage volume debris in ice, for basal ice facies and sub-facies at Russell Glacier, with calculated annual debris flux per linear metre of ice margin

\begin{tabular}{|c|c|c|c|c|c|c|c|}
\hline \multirow[t]{3}{*}{$\begin{array}{l}\text { Facies } \\
\quad \text { (sub-facies) }\end{array}$} & \multicolumn{3}{|c|}{$\begin{array}{l}\text { Debris concentration } \\
\text { (volume) }\end{array}$} & \multicolumn{3}{|c|}{ Thickness } & \multirow[t]{2}{*}{ Debris flux } \\
\hline & Mean & $n$ & $S D$ & Mean & $S D$ & $\%$ offacies & \\
\hline & $\%$ & & & $\mathrm{~m}$ & & & $\mathrm{~m}^{3} \mathrm{~m}^{-1} \mathrm{a}^{-1}$ \\
\hline Dispersed & 2 & 6 & 1.7 & 15.00 & 3.10 & 100 & 7.2 \\
\hline Stratified & 39.15 & 29 & $\mathrm{n} / \mathrm{a}$ & 1.40 & 0.80 & 100 & 13.15 \\
\hline (solid) & 47.2 & 10 & 10.6 & 1.01 & 0.49 & 72.2 & 11.44 \\
\hline (discontinuous) & 17.0 & 13 & 9.8 & 0.30 & 0.11 & 21.4 & 1.22 \\
\hline (suspended) & 22.7 & 6 & 9.9 & 0.09 & 0.06 & 6.4 & 0.49 \\
\hline Total & & & & & & & 20.35 \\
\hline
\end{tabular}

tage volume of debris in melt was then multiplied by 0.9 to make an approximate allowance for the difference in density between ice and water to calculate percentage volume of debris in ice. Samples were collected from each sub-facies at intervals throughout the $1 \mathrm{~km}$ field area, and calculations of debris content were based on the combined mean values for each sub-facies (a total of 35 samples; Table 2). For the dispersed facies, field sampling was difficult because of the low debris content and the distribution of the debris in distinct aggregates or "clots" dispersed within otherwise clean ice (Knight and others, 1994), so we checked our field measurements by an additional method as follows. The debris content of individual clots was measured (mean $75.5 \%$, standard deviation $0.5 \%$ ) by the method described above, and the concentration of clots in ice was measured photographically by calculating the areal coverage of clots on shallow-focus images of large $\left(0.5-1 \mathrm{~m}^{2}\right)$ sections through the dispersed facies. The overall debris content of the dispersed facies was calculated by combining the debris content per clot and the concentration of clots in ice. The results were consistent with the measured values presented in Table 2 that were used for this study. The bulk debris concentration in the stratified facies was calculated as a mean of the debris concentration in individual sub-facies weighted by the relative proportions of these subfacies within the stratified facies. Therefore, the actual mean and standard deviation of the individual measurements are not given for the (bulk) stratified-facies data, but only for the individually measured sub-facies.

\section{OBSERVATIONS}

The overall structure of the basal ice layer was similar to that previously described from several sites in West Greenland (e.g. Sugden and others, 1987; Souchez and others, 1990, 1993; Souchez and Lorrain, 1991; Knight and others, 1994; Waller and others, 2000), comprising stratified and dispersed facies, characteristics of which are shown in Tables 1 and 2. Figures 


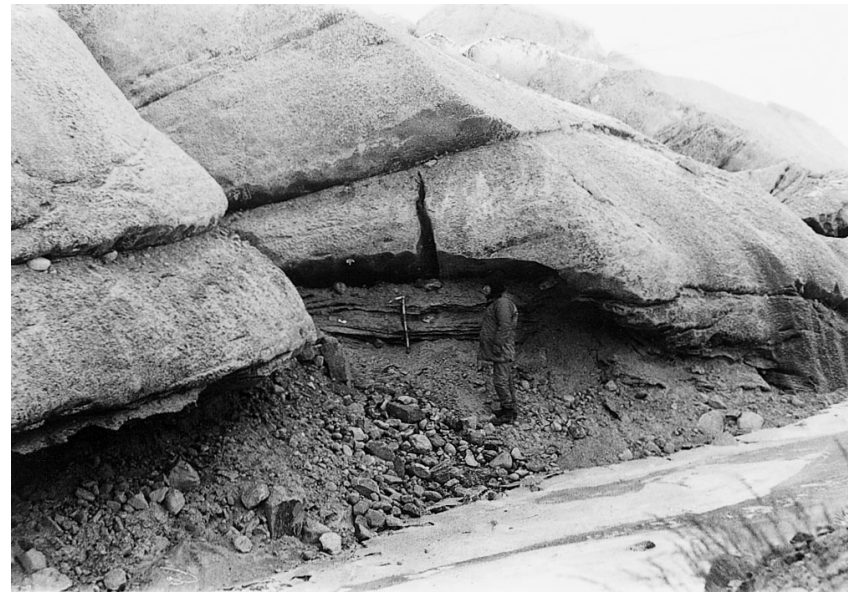

Fig. 2. Typical morphology of the ice margin in the study area. Note person for scale in centre of image.

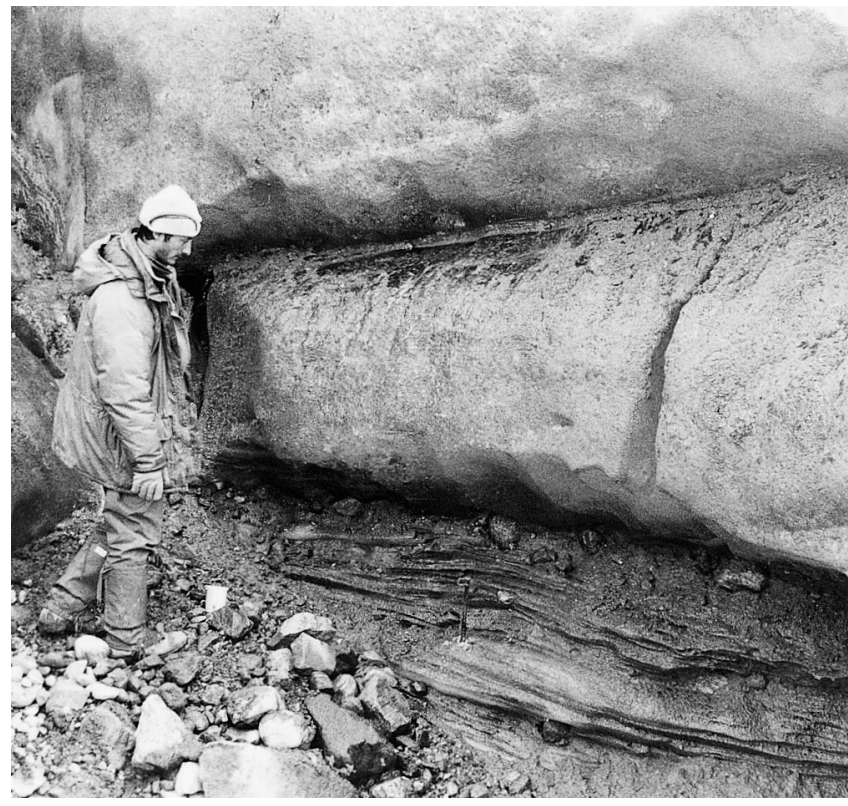

Fig. 3. Close-up view of the area in the centre of Figure 2, showing characteristic stratigraphy of the basal ice with a bottom layer of stratified-facies ice (below level of person's hand) overlain by several metres of dispersed-facies ice intercalated with debris bands.

2-4 illustrate these facies at the ice margin at the study area. Stratified-facies basal ice occurred at the bottom of the sequence, comprising three intercalated sub-facies characterized as solid, discontinuous and suspended following Lawson's (1979) classification scheme. The solid sub-facies comprised diamict with interstitial ice and small ice lenses, with a mean debris concentration of $47.2 \%$ by volume. The discontinuous sub-facies was dominated by ice with laminae of sand and fine gravel, with a mean debris concentration of $17 \%$ by volume. The suspended sub-facies comprised ice with scattered particles and aggregates of sand and silt, with a mean debris concentration of $22.7 \%$ by volume. Debris bands $\leq 20 \mathrm{~cm}$ thick extended from the top of the stratified facies, dipping up-glacier and penetrating into the overlying ice down-glacier. The number of debris bands in the basal sequence varied from 0 to 20 , with a debris composition indistinguishable from that of the stratified facies, including all three sub-facies. In our calculations of debris flux we aggregate the data for the debris bands and the stratified facies, because they are structurally and sedimentologically

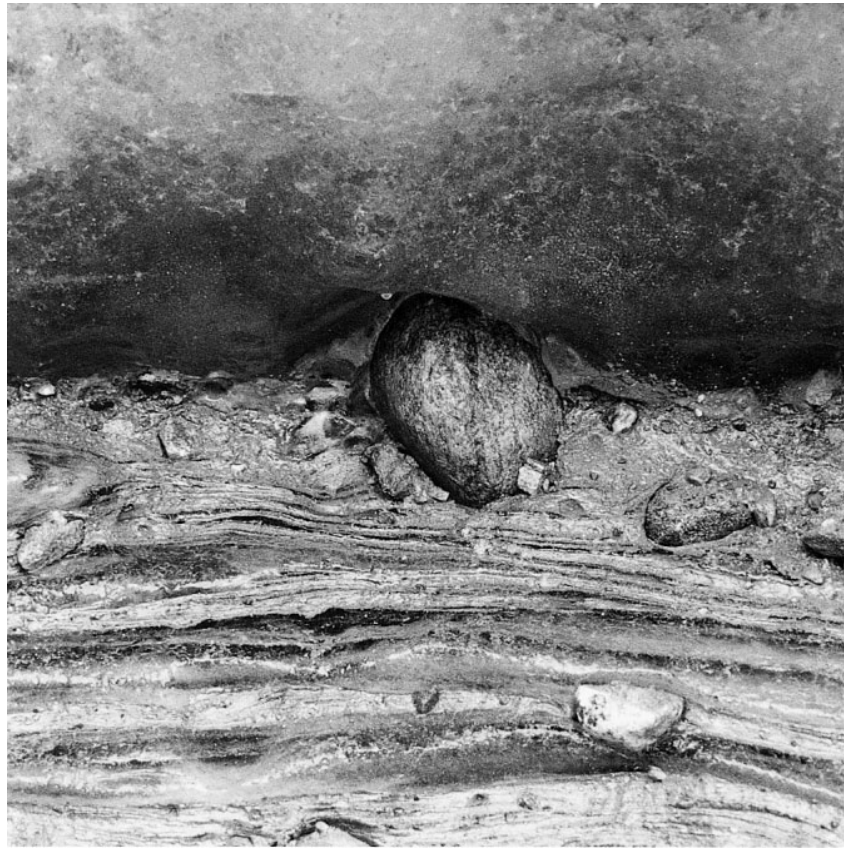

Fig. 4. Close-up view of the area in the lower centre of Figure 3, showing the boundary between stratified- (below) and dispersed-facies ice. Within the stratified facies it is also possible to distinguish both discontinuous sub-facies ice (the bottom third of the image) and solid sub-facies ice (the boulder-rich band in the centre of the image).

related (Knight, 1994) and differ only in their stratigraphic setting. Dispersed-facies basal ice, occurring directly above the stratified facies, consisted of silt-clay aggregates in a matrix of debris-free ice. The maximum observed thickness of the stratified facies (excluding debris bands) was $2.5 \mathrm{~m}$, and of the dispersed facies $20 \mathrm{~m}$. Including debris bands of stratified-facies ice intercalated with overlying dispersed and englacial facies, the maximum total thickness of the basal sequence approached $30 \mathrm{~m}$.

Englacial (non-basal) ice was distinguished from the basal ice by its higher bubble content, bubble foliation and lower debris content. Previous studies at this site have also shown it to be isotopically distinctive (e.g. Sugden and others, 1987). The only debris source for the englacial ice was supraglacial accumulation in the central area of the ice sheet. Although particles of very fine-grained debris were visible within the englacial facies, they were so few that our ice samples of $\sim 2000 \mathrm{~cm}^{3}$ did not provide sufficient debris to conduct any analysis, so for the purpose of this study we consider the englacial debris content to be negligible. Previously published data from other sites (Table 3 ) offer measured values of $0.002-0.6 \%$ volume debris in ice for englacial facies even in environments that have abundant debris sources in the accumulation area.

Subglacial sediment was highly variable in thickness. The ground surface in the study area typically comprised bedrock with only a thin, discontinuous covering of sediment. Where the glacier substrate was visible to bedrock, there was no subglacial layer of diamicton, and basal stratified-facies ice rested directly on rock. However, parts of the ice margin were overriding a fringing moraine ridge, and in those locations the ice was underlain by up to $30 \mathrm{~m}$ of diamicton. Localized entrainment of subglacial debris into the basal ice by folding and by freezing was observed, but no evidence was found, either in the basal sequence or in 
Table 3. Summary of debris concentration in ice for different facies of Russell Glacier (this study) and selected other glaciers (various sources)

\begin{tabular}{|c|c|c|c|c|c|c|}
\hline $\begin{array}{l}\text { Facies } \\
\quad \text { (sub-facies) }\end{array}$ & $\begin{array}{l}\text { Russell } \\
\text { Glacier }\end{array}$ & $\begin{array}{c}\text { Jakobshavn, } \\
\text { Greenland } \\
\text { (ref.1) }\end{array}$ & $\begin{array}{c}\text { Matanuske } \\
\text { Alaska } \\
\text { (ref.2) }\end{array}$ & $\begin{array}{l}3 \text { glaciers, } \\
\text { Alaska } \\
\text { (ref.3) }\end{array}$ & $\begin{array}{l}\text { Variegated } \\
\text { Alaska } \\
\text { (ref.4) }\end{array}$ & $\begin{array}{c}\text { 1, Meserve, } \\
\text { Antartica } \\
\text { (ref.5) }\end{array}$ \\
\hline $\begin{array}{l}\text { Englacial } \\
\text { (diffused) }\end{array}$ & $\sim 0$ & - & 0.002 & $0.1-0.6$ & 0.3 & 0.028 \\
\hline Basal dispersed & 2.0 & - & 3.8 & $0.1-1.4$ & 0.4 & 0.818 \\
\hline Basal stratified & 39.1 & - & 25 & - & - & - \\
\hline (solid) & 47.2 & 30 & $>60$ & $9.8-22.4$ & 35.7 & - \\
\hline (discontinuous) & 17.0 & 15 & $0.2-36$ & & 10.9 & - \\
\hline (suspended) & 22.7 & - & $0.2-60$ & $0.9-3.9$ & 0.4 & - \\
\hline
\end{tabular}

Sources of previously released data: 1. Sugden and others $(1987)^{* \dagger} ; 2$. Lawson (1979); 3. Hunter and others (1996a); 4. Sharp and others $(1994)^{*} ; 5$. Cuffey and others $(2000)^{*} ;$ K. M. Cuffey (personal communication, 2001).

* Original facies classification used different terminology.

${ }^{\dagger}$ Data converted from concentrations measured by weight.

exposed subglacial sediments, of widespread subglacial transport of unfrozen debris by deformation. Frozen debris attached to the glacier sole was considered to be part of the basal stratified solid sub-facies.

Supraglacial debris at this site was derived only from aeolian sources and from melt-out from surface outcrops of basal ice. There were no supraglacial rock sources such as valley sides or nunataks, and although isolated particles of windblown silt were present on the glacier surface throughout the study area, the volume of supraglacial debris was negligible.

No debris transport in meltwater streams emerging from the ice occurred in the study area, which was deliberately selected to illustrate conditions at ice margins between meltwater outlets. Field observations and analysis of aerial photographs of $14 \mathrm{~km}$ of the ice margin including our $1 \mathrm{~km}$ study section indicated that $77 \%$ of the length of the margin was completely unaffected by meltwater outlets, icemarginal lakes or contact with proglacial streams.

\section{DEBRIS FLUX}

The annual release of debris from the ice can be calculated from the debris concentration in the ice and the discharge of ice through the margin. Thus for each facies:

$$
s=\frac{z d v y}{y},
$$

where $s$ is sediment discharge $\left(\mathrm{m}^{3} \mathrm{~m}^{-1} \mathrm{a}^{-1}\right), z$ is facies thickness $(\mathrm{m}), d$ is debris content ( $\%$ volume), $v$ is linear ice discharge $\left(\mathrm{m} \mathrm{a}^{-1}\right)$ and $y$ is length of margin $(\mathrm{m})$. The linear discharge of ice at the margin can be estimated by comparing the forward motion of the ice surface with the changing position of the margin. We base our estimate on (1) the ice velocity close to the margin (Sugden and others 1987; Knight, 1992); (2) seasonal advance and recession of the margin in response to seasonal variations in ablation (Knight and others, 2000); (3) the long-term rate of advance of the margin (Knight and others 2000); and (4) the local ablation rate (Van de Wal, 1992; Van Tatenhove and others, 1995). The mean annual advance of the ice margin between 1984 and 1999 was $1.7 \mathrm{~m} \mathrm{a}^{-1}$, but mean forward ice motion in the marginal zone based on measurements during both summer and winter at intervals throughout that period was $25.7 \mathrm{ma}^{-1}$. From these data we estimate the annual discharge of ice at this site to be equivalent to a forward motion of approximately $24 \mathrm{~m}$. By this we mean that if no ablation occurred, the margin would advance by an additional $24 \mathrm{~m} \mathrm{a}^{-1}$ relative to its actual movement. Due to ablation, this amount of ice is lost, and its debris load is released. The annual discharge of individual ice facies, of debris from within each facies and of debris from the whole basal ice sequence can then be calculated from the equation above using our measured values of debris content and thickness for each facies (Table 2). The calculated value for the total debris flux from the basal ice is $20.35 \mathrm{~m}^{3} \mathrm{~m}^{-1} \mathrm{a}^{-1}$. The debris flux from other glacial sources (englacial facies and supraglacial material not derived from basal ice) in the study area is negligible. The calculation assumes that there is no vertical variation in flow rate through the basal ice. This assumption is supported by data provided by R. I. Waller and J. K. Hart (http://boris.qub.ac. uk/ggg/papers/full/1999/rp021999/rp02.html) who showed that motion in the basal layers of Russell Glacier was accommodated primarily by basal sliding with very little internal deformation within the basal ice.

Whether our calculated debris flux is realistic depends on: the potential error of our measurements of debris content per sub-facies and of facies and sub-facies thickness; the accuracy of our estimate of annual ice flux at the margin; and the natural variability in the debris distribution in the ice. Variability in the data is suggested by the standard deviations given in Table 2. The limited size of our dataset increases the standard deviations that we record, and limits the precision of our calculation of debris flux, but nevertheless provides a likely range within which to constrain the value. Likely error in the estimate of ice flux is harder to quantify as it is based on data from different sources. However, if we assume a possible error of $\pm 10 \%$, we can calculate sediment flux per sub-facies and for the whole sequence at maximum and minimum estimated values one standard deviation above and below the measured debris content and facies thickness, and $10 \%$ above and below the estimated ice discharge. The range of values that we then calculate for the total debris flux is $12.3-44.8 \mathrm{~m}^{3} \mathrm{~m}^{-1} \mathrm{a}^{-1}$. The estimate of potential error appears greater above our primary estimate than below it because it is based partly on applying \% error values to numerical values for debris volumes. Taking the midpoint between the extremes of our range of estimates would suggest an alternative approximation of the debris flux of $28.5 \pm 16.2 \mathrm{~m}^{3} \mathrm{~m}^{-1} \mathrm{a}^{-1}$.

We follow Small and others (1984) in giving sediment values as volumes produced per linear metre of ice margin, rather than offering sediment yields in tonnes or in $\mathrm{mm}$ erosion per area of ice cover, because it is not possible to identify with confidence the subglacial catchment area for short sections of ice-sheet margin, and because our site was chosen as one that did not reflect glaciofluvial evacuation of subglacial material derived from the deep interior of the ice sheet. Our measurements describe the release of debris at the margin, and we do not directly infer any geography of denudation rates beneath the interior of the ice sheet.

\section{DISGUSSION}

These observations indicate that, at sections of the terrestrial margin of the ice sheet in West Greenland that are unaffected by meltwater discharge, transport of debris through the basal ice layer dominates sediment production. 
Sediment delivery from englacial and supraglacial sources is negligible. Our $1 \mathrm{~km}$ study area on the flank of an ice-sheet outlet was specifically chosen to be characteristic of sections of the ice-sheet margin that do not discharge interior-derived meltwater. Additional data from other types of margin in marine or meltwater-dominated environments are required before generalizations can be made about sediment discharge from the ice sheet as a whole, but these results quantify the glacial debris flux for one important type of ice-sheet margin environment where glaciofluvial and englacial sediment transfer is negligible. In West Greenland, such sections can be many $\mathrm{km}$ long, and represent about $77 \%$ of the total icesheet margin in the region.

Our observations of individual sub-facies within the basal ice are consistent with previous studies in the same area and more broadly in West Greenland. Sugden and others (1987), Knight and others (2000) and Waller and others (2000) made measurements over longer sections of the ice margin at Russell Glacier that indicated the same relative proportions of debris in ice that we have described. Data from other sites elsewhere in West Greenland are also broadly consistent with our observations. For example, Sugden and others (1987) reported stratified-facies debris concentrations of $34 \%$ and $55 \%$ (by weight) for facies equivalent to the discontinuous and solid sub-facies at Jakobshavn Isbræ. Converting those measurements to percentage volume (assuming densities of 0.9 for ice and 2.7 for rock debris) suggests values of $\sim 15 \%$ and $\sim 30 \%$, compared with their (converted) values for Russell Glacier of $\sim 6 \%$ and $45 \%$, and our values of $17 \%$ and $47 \%$. Observations from some other locations outside Greenland indicate similar relative debris concentrations within individual basal facies (Table 3). For example, for Matanuska Glacier, Alaska, U.S.A., Lawson (1979, p.7) described mean debris concentrations in the dispersed and stratified facies, respectively, of $3.8 \%$ and $25 \%$ (by volume) compared with our values of $2 \%$ and $39 \%$. Although there are variations within sample sets (indicated by the standard deviations in Table 2), the relative proportions are reasonably consistent between sites, suggesting that our site is representative of an extensive section of the ice-sheet margin in West Greenland.

Sediment flux from glaciers is a major part of the global sediment flux from land to oceans. However, its relative significance, the relative contributions of different types of glaciers, and by implication the effectiveness of ice sheets as agents of erosion, remain controversial (Hallet and others,
1996; Hay, 1998). One potential application of data on glacial sediment discharge is the calculation of regional subglacial denudation rates. For example, Hallet and others (1996) expressed diverse field data on glacial sediment yields as effective rates of glacial erosion. They found rates to vary from $0.01 \mathrm{~mm} \mathrm{a}^{-1}$ for polar glaciers and thin temperate plateau glaciers on crystalline bedrock, to $10-100 \mathrm{~mm} \mathrm{a}^{-1}$ for large, fast-moving temperate valley glaciers in the tectonically active ranges of southeast Alaska. However, most of these data were acquired by a variety of different methods that involved measurements of sediment volume produced from a glacierized area of known extent. The calculation of areal erosion rates from volumes of sediment is limited not only by the completeness of capture of released sediment, but also by the accuracy of measurement of the size of the glaciated catchment area. Our data from West Greenland provide a complete measure of debris release from the terrestrial ice margin, but, in common with most other studies of ice-sheet drainage basins, cannot be constrained to a precisely delimited subglacial catchment area. As subglacial topography and flow of ice in the ice sheet is not known, we cannot realistically infer areal erosion rates to compare with previous studies. However, we can closely constrain the actual sediment discharge through the ice margin, and make direct comparisons with other studies that have made such direct measurements.

Our observations of glacial debris transfer at Russell Glacier agree closely with measurements at adjacent Leverett Glacier, 4 km south of our site (Van Tatenhove, 1995; Table 4). However, they differ substantially from those of many previous studies in different glacial settings, both in the rate of sediment production and in the relative importance of different transport routes through the glacier. For example, Small and others (1984) found that marginal sediment output at Glacier de Tsidjiore Nouve, Switzerland, was derived mainly from supraglacial and englacial sources. By contrast, Hunter and others (1996a) found that at three Alaskan tidewater glaciers glaciofluvial sources provided orders of magnitude more sediment to the debris flux than did glacial sources, which was not the case at the Russell Glacier site. Gustavson and Boothroyd (1987) argued that debris in basal ice was not a significant part of the process of sediment transport to the margin of glaciers such as Malaspina Glacier, Alaska, or the Laurentide ice sheet, and that sediments were derived mostly from subglacial fluvial erosion, transported to the margin

Table 4. Sediment production at the margin of Russell Glacier (this study) and at other modern and former glaciers (from various sources)

\begin{tabular}{lcl} 
Site & Sediment production & Source \\
& $\mathrm{m}^{3} \mathrm{~m}^{-1} \mathrm{a}^{-1}$ & \\
\hline Vestfold Hills, East Antarctica & $0.045-0.089$ & Calculated from data in Fitzsimons (1997) \\
Byrd Station, Antarctica & $0-4^{*}$ & Based on data in Gow and others (1979); Whillans (1983) \\
Fjallsjökull, Iceland & $4.5^{\dagger}$ & Price (1970) \\
Bødalsbreen, Norway & $1.7^{\dagger}$ & Matthews and others (1979) \\
Glacier de Tsidjiore Nouve, Switzerland & $2-8$ & Small and others (1984) \\
Russell Glacier, West Greenland & $12.3-44.8$ & This study \\
Leverett Glacier, West Greenland & 60 & VanTatenhove (1995) \\
Lake Michigan lobe, Laurentide ice sheet & $185-890^{*}$ & LaBlanc (2001); LaBlanc and others (unpublished information) \\
Three tidewater glaciers, Alaska & $500-1500$ & Hunter and others (1996a) \\
Bear Island Fan, Barents Sea ice sheet & $\sim 1500$ & Calculated from data in Dowdeswell and Siegert (1999)
\end{tabular}

${ }^{*}$ Flux at a point in the interior, not at the margin.

${ }^{\dagger}$ Based on calculations by Van Tatenhove (1995). 
through tunnels. Evenson and Clinch (1987) also found that englacial and subglacial transport delivered no significant amount of material to the margin of alpine glaciers in Alaska, while the bulk of debris was delivered by fluvial systems. They also found that basal debris transport was difficult to evaluate, that the glacier itself was not a major sediment source, and that sediment routed to the proglacial area was derived primarily from non-glacial sources. By contrast, in Greenland we found that the basal transport zone was easily accessible in ice cliffs and ice ramps with thick exposures of debris-bearing basal ice, and that virtually all of the sediment delivered to the ice margin was derived directly from glacial sources. Our observations correspond with those of Dowdeswell (1986), who recorded a thick basal layer as a dominant sediment source at the margin of Watts Glacier, Baffin Island, Canada; Andrews and others (1994), who suggested that sediment flux through three East Greenland fjord glaciers was dominated by glacial debris rather than meltwater-derived sediments; and R. D. Powell and others (unpublished information), who found that sediment from Mackay Glacier, Antarctica, was transported by subglacial deformation and as basal debris.

Table 4 indicates that there are several orders of magnitude difference in sediment production rates between different glaciers. This is consistent with the observation by Hallet and others (1996) that rates of glacial erosion vary by orders of magnitude between different environments. Our site at Russell Glacier and Van Tatenhove's (1995) site at nearby Leverett Glacier share sediment production rates three orders of magnitude higher than that reported for East Antarctica, an order of magnitude higher than those reported for sites in Norway, Iceland and Switzerland, but an order of magnitude lower than the value reported from Alaska and other highrate environments such as surging glaciers reported by Van Tatenhove (1995). Sites where large amounts of unconsolidated material in the forefields of advancing glaciers facilitate local remobilization of sediment by processes such as glacial pushing can also be characterized by high sediment fluxes, although these may not be related to bedrock erosion.

These data demonstrate that mechanisms and volumes of glacial debris flux vary between locations, that care must be taken in transferring models of glacial sediment production between environments, and that measurements from different types of environment are required to constrain regional or global models of glacial erosion or sediment production. The distinction between glacial environments with different relative proportions of glacial and fluvioglacial sediment is consistent with previous descriptions of debris-rich basal ice in different environments (e.g. Boulton, 1970; Clapperton, 1975). Thermal regime, lithology and flow velocity may be significant controls on subglacial debris entrainment and transport, while meltwater production and routing at the glacier bed are important to fluvioglacial sediment transfer. Our site in West Greenland is typical of many of the sites reported to have thick debris-rich basal ice, in that it is a subpolar margin experiencing dominantly compressive ice flow towards the margin (Knight, 1992) and limited subglacial meltwater discharge. It is likely that characteristics of icemarginal sediment discharge closely reflect patterns of formation of debris-rich basal ice, which have previously been related to specific thermal or pressure regimes where material freezes to the bed and is raised into the ice by compressive deformation (e.g. Boulton, 1970; Harris and Bothamly, 1984; Knight, 1994). However, the relationship between sediment flux and subglacial environment is complex, and not yet fully understood. It is still not possible to infer specific subglacial conditions from measured or calculated debris fluxes in the manner attempted by Alley (1991). Flux rates at any location may be controlled by complex combinations of sediment routing (deforming till, basal layer, fluvioglacial, supraglacial) and the subglacial conditions that determine that routing (thermal regime, sediment availability, topography). For example, it is impossible to determine whether the high flux rates envisaged at specific locations beneath the southern Laurentide ice sheet downstream from former lake basins (e.g. K.J. LaBlanc and others, unpublished information) are due to till deformation, to enhanced basal entrainment as a result of substrate characteristics (sediment availability) or to enhanced basal entrainment as a result of topographically induced basal freezing.

Nevertheless, sediment-production rates such as those that we have produced do have value in Quaternary reconstruction, for example in the use of moraine volumes to reconstruct the duration of glacial occupancy of a site (e.g. Van Tatenhove, 1995; Fitzsimons, 1997). Moraine-sediment budgets require knowledge of both inputs and outputs of sediment, but the supply of sediment to the moraine is probably the rate-limiting factor in moraine growth, especially in environments where meltwater discharge is limited. At our site and analogous locations, debris transfer through basal ice is the dominant control on moraine growth, and a key variable in reconstructing glacial history from moraine morphology.

Our observations suggest that, at least locally, debris transfer through basal ice is proportionally much more important at the terrestrial margin of the Greenland ice sheet than at many other locations. However, ice-sheet margins are characterized by variability, and further studies are required in different ice-sheet environments to qualify the results of our investigation. Our observations provide data about one type of ice-marginal setting: an interfluve area at a terrestrial icesheet margin. This type of environment is not well represented in previous literature concerning debris flux and sediment yields, but is morphologically characteristic of many locations in both modern and ancient ice-sheet settings. Further work is required to elaborate the proportion of contemporary and ancient ice-sheet margins characterized by these environments, their relative contribution to the total sediment discharge from the ice sheet, and the sedimentological implications of environmental controls such as thermal regime, flow velocity and substrate characteristics.

\section{GONGLUSION}

At the margin of the Greenland ice sheet near Kangerlussuaq, large amounts of debris are transported to the margin in a debris-rich layer of basal ice up to $30 \mathrm{~m}$ thick. The basal ice discharges debris at a rate of $12.3-44.8 \mathrm{~m}^{3} \mathrm{~m}^{-1} \mathrm{a}^{-1}$, which constitutes the majority of the sediment released from the ice margin in the study area. Only negligible amounts are transferred through englacial, supraglacial or subglacial routes. Glaciofluvial sediment transfer is highly localized, and sections of the ice margin many $\mathrm{km}$ in length, comprising $77 \%$ of the ice margin in the vicinity of the study area, receive no sediment from glaciofluvial sources. The supply of debris to the moraines that mark the margin of the ice sheet is almost entirely through the basal ice layer, and debris supply through the basal ice may be the rate-limiting factor in moraine growth. 
Our data describe the characteristics of a terrestrial margin between meltwater outlets. Bulk sediment discharge for the ice sheet as a whole may involve a substantial glaciofluvial component, but at the scale of sections of the ice margin many $\mathrm{km}$ in length, sediment transfer is dominated by the discharge of sediment from basal ice. These findings differ from those of studies in some other glacial settings, and suggest that sediment-budget models may not be transferable between glacial environments. Care must therefore be taken when modelling the characteristics of former ice sheets on supposed modernday analogues. This work provides data about debris flux through ice at one type of ice-sheet setting that can be combined with data from other ice-sheet environments to contribute to a general model of ice-sheet debris production.

\section{AGKNOWLEDGEMENTS}

This research was funded by a grant from the Royal Society. Permission to carry out the fieldwork was granted by the Danish Polar Centre. The authors are grateful to K. M. Cuffey, R. D. Powell, M. Sturm, P. Jansson, K. LaBlanc and an anonymous referee for advice and information.

\section{REFERENCES}

Alley, R. B. 1991. Deforming-bed origin for southern Laurentide till sheets? f. Glaciol., 37(125), 67-76.

Andrews, J. T., J. D. Milliman, A. E. Jennings, N. Rynes and J. L. Dwyer. 1994. Sediment thicknesses and Holocene glacial marine sedimentation rates in three East Greenland fjords (ca. $\left.68^{\circ} \mathrm{N}\right)$. F. Geol., 102(6), 669-683.

Boulton, G. S. 1970. On the origin and transport of englacial debris in Svalbard glaciers. F. Glaciol., 9(56), 213-229.

Clapperton, C. M. 1975. The debris content of surging glaciers in Svalbard and Iceland. F. Glaciol., 14(72), 395-406.

Cuffey, K. M., H. Conway, A. Gades, B. Hallet, C. F. Raymond and S. Whitlow. 2000. Deformation properties of subfreezing glacier ice: role of crystal size, chemical impurities, and rock particles inferred from in situ measurements. 7. Geophys. Res., 105(B12), 27,895-27,915.

Dowdeswell, J. A. 1986. The distribution and character of sediments in a tidewater glacier, southern Baffin Island, N.W.T., Canada. Arct. Alp. Res., 18(1), 45-56.

Dowdeswell, J. A. and M. J. Siegert. 1999. Ice-sheet numerical modelling and marine geophysical measurements of glacier-derived sedimentation on the Eurasian Arctic continental margins. Geol. Soc. Am. Bull., 111 (2), 1080-1097.

Evenson, E. B. and J. M. Clinch. 1987. Debris transport mechanisms at active alpine glacier margins: Alaska case studies. In Kujansuu, R. and M. Saarnisto, eds. INQUA Till Symposium, Finland 1985. Espoo, Geological Society of Finland, 111-136. (Geol. Surv. Finl. Spec. Pap 3.)

Fitzsimons, S. J. 1997. Depositional models for moraine formation in East Antarctic coastal oases. f. Glaciol., 43(144), 256-264.

Gow, A. J., S. Epstein and W. Sheehy. 1979. On the origin of stratified debris in ice cores from the bottom of the Antarctic ice sheet. F. Glaciol., 23(89), 185-192.

Gustavson, T. C. and J. C. Boothroyd. 1987. A depositional model for outwash, sediment sources, and hydrologic characteristics, Malaspina Glacier, Alaska: a modern analog of the southeastern margin of the Laurentide ice sheet. Geol. Soc. Am. Bull., 99(2), 187-200.

Hallet, B., L. E. Hunter and J. Bogen. 1996. Rates of erosion and sediment evacuation by glaciers: a review of field data and their implications. Global Planet. Change, 12(1-4), 213-235.

Harris, C. and K. Bothamley. 1984. Englacial deltaic sediments as evidence for basal freezing and marginal shearing, Leirbreen, southern Norway. 7. Glaciol., 30(104), 30-34.

Hay, W.W. 1998. Detrital sediment fluxes from continents to oceans. Chemical
Geol., 145(3-4), 287-323.

Hubbard, B. and M. Sharp. 1995. Basal ice facies and their formation in the western Alps. Arct. Alp. Res., 27(4), 301-310.

Hunter, L. E., R. D. Powell and D. E. Lawson. 1996a. Flux of debris transported by ice at three Alaskan tidewater glaciers. F. Glaciol., 42(140), 123-135.

Hunter, L. E., R. D. Powell and D. E. Lawson. 1996b. Morainal-bank sediment budgets and their influence on the stability of tidewater termini of valley glaciers entering Glacier Bay, Alaska, U.S.A. Ann. Glaciol., 22, 211-216.

Knight, P. G. 1992. Ice deformation very close to the ice-sheet margin in West Greenland. f. Glaciol., 38(128), 3-8.

Knight, P. G. 1994. Two-facies interpretation of the basal layer of the Greenland ice sheet contributes to a unified model of basal ice formation. Geology, 22(11), 971-974.

Knight, P. G., D. E. Sugden and C. D. Minty. 1994. Ice flow around large obstacles as indicated by basal ice exposed at the margin of the Greenland ice sheet. f. Glaciol., 40(135), 359-367.

Knight, P. G., R. I. Waller, C. J. Patterson, A. P. Jones and Z. P. Robinson. 2000. Glacier advance, ice-marginal lakes and the routing of meltwater and sediment: Russell Glacier, Greenland. F. Glaciol., 46(154), 423-426.

LaBlanc, K. J. 2001. A GIS-based study of sedimentation rates and sediment fluxes of the Lake Michigan and Green Bay Lobes of the Southern Laurentide ice sheet. (M.Sc. thesis, University of Wisconsin-Madison.)

Lawson, D. E. 1979. Sedimentological analysis of the western terminus region of the Matanuska Glacier, Alaska. CRREL Rep. 79-9.

Matthews, J. A., R. Cornish and R. A. Shakesby. 1979. "Saw-tooth" moraines in front of Bødalsbreen, southern Norway. 7. Glaciol., 22(88), 535-546.

Post, A. 1975. Preliminary hydrography and historic terminal changes of Columbia Glacier, Alaska. U.S. Geol. Surv. Hydrol. Invest. Atlas HA-559, 3 maps (scale 1:10,000).

Powell, R. D. 1991. Grounding-line systems as second-order controls on fluctuations of tidewater termini of temperate glaciers. In Anderson, J. B. and G. M. Ashley, eds. Glacial marine sedimentation; paleoclimatic significance. Boulder, CO, Geological Society of America, 75-93. (GSA Special Paper 261.)

Price, R. J. 1970. Moraines at Fjallsjökull, Iceland. Arct. Alp. Res., 2(1), $27-42$.

Sharp, M., J. Jouzel, B. Hubbard and W. Lawson. 1994. The character, structure and origin of the basal ice layer of a surge-type glacier. 7. Glaciol., 40(135), 327-340.

Small, R. J. 1987. Moraine sediment budgets. In Gurnell, A. M. and M. J. Clark, eds. Glacio-fluvial sediment transfer: an alpine perspective. Chichester, etc., John Wiley and Sons, 165-197.

Small, R. J., I. R. Beecroft and D. M. Stirling. 1984. Rates of deposition on lateral moraine embankments, Glacier de Tsidjiore Nouve, Valais, Switzerland. 7. Glaciol., 30 (106), 275-281.

Souchez, R. A. and R. D. Lorrain. 1991. Ice composition and glacier dynamics. New York, etc., Springer-Verlag. (Springer Series in Physical Environment 8.)

Souchez, R., M. Lemmens, R. Lorrain, J.-L. Tison, J. Jouzel and D. Sugden. 1990. Influence of hydroxyl-bearing minerals on the isotopic composition of ice from the basal zone of an ice sheet. Nature, 345 (6272), 244-246.

Souchez, R., M. Lemmens, J.-L. Tison, R. Lorrain and L. Janssens. 1993. Reconstruction of basal boundary conditions at the Greenland ice sheet margin from gas composition in the ice. Earth Planet. Sci. Lett., 118(1-4), 327-333.

Sugden, D. E. and 6 others. 1987. Evidence for two zones of debris entrainment beneath the Greenland ice sheet. Nature, 328(6127), 238-241.

Van de Wal, R. S.W. 1992. Ice and climate. (Ph.D. thesis, Utrecht University.)

Van Tatenhove, F. G. M. 1995. The dynamics of Holocene deglaciation in West Greenland with emphasis on recent ice-marginal processes. (Ph.D. thesis, University of Amsterdam.)

Van Tatenhove, F. G. M., C. M. Roelfsema, G. Blommers and A. van Voorden. 1995. Change in position and altitude of a small outlet glacier during the period 1943-92: Leverett Glacier, West Greenland. Ann. Glaciol., 21, 251-258.

Waller, R. I., J. K. Hart and P. G. Knight. 2000. The influence of tectonic deformation on facies variability in stratified debris-rich basal ice. Quat. Sci. Rev., 19(8), 775-786.

Whillans, I. M. 1983. Glaciological parameters, their measurement and significance. Ice movement. In Robin, G. de Q., ed. The climatic record in polar ice sheets. Cambridge, etc., Cambridge University Press, 70-77. 